\title{
Seroepidemiological study for the prevalence of Neospora caninum in Dairy \& Beef cattle in some Iraqi provinces
}

M.O.Mallah

Coll. of sci./ Unive.of Al-Muthana
Kh. A. Dawood M. A. Alrodhan

Coll.of Vet.Med./ Unive. Al-Qadyssia

\begin{abstract}
A Seroepidemiological study of Neospora caninum was conducted in Al-Muthana and Al-Nasseria provinces, Iraq on 800 cows serum sample by using commercial Elisa kit. the overall seroprevalence ratio of Neospora caninum was $17.5 \%$, on provincial basis Neospora caninum infection was present in these provinces that was $16 \%, 18.4 \%$ in Al-Muthana, and Al-Nasseria provinces respectively, which non significant differences between provinces $(\mathrm{P}<0.05)$, Comparisons of N.caninum serological status with age groups $(5-8 \mathrm{y})$ showed seropositive rate $21.32 \%$ that higher thanother groups with significant differences $(\mathrm{P}<0.05)$. antibodies of N.caninum showed in aborted cows 32.29\% higher than non aborted cows $7.53 \%$ with significant differences $(\mathrm{P}<0.05)$. Also the infection rate in dairy cows $19.17 \%$ higher than beef cows $12.5 \%$ with significant differences $(\mathrm{P}<0.05)$.
\end{abstract}

\section{Introduction :}

Neosporosis is a parasitic disease caused by Neospora caninum, a protozoan that until1988 was misdiagnosed as Toxoplasma gondii because of close structural similarities(1,2). Phylogenic studies showed that it is very closely related to Toxoplasma gondii and it is now placed as the sister group of Toxoplasma gondii (3).some studies have been conducted to assess the prevalence and to identify factors related to the disease, Prevalence's have been estimated in ranges between $16.8 \%$ and $70 \%$. $(4,10,11)$.Neospora caninum infections have been reported from most parts of the world and seroprevalences for each host were tabulated recently, quantitative studies involving a large number of fetuses in many countries indicate that $12 \%$ to $42 \%$ of aborted fetuses from dairy cattle are infected with Neospora caninum, also in serologic prevalence in cattle varies, depending on the country, region, type of serologic test used, and cutoff level used to determine the exposure. (8). Seroepidemiological studies have assessed the increased risk for abortion in seropositive cows $(5,41,11)$.The risk of being seropositive may increase with age or parity number in beef and dairy cattle due to horizontal transmission of $N$. caninum by ingestion of oocysts shed by definitive hosts (7). However, the age effect might be influenced by management practices such as replacement rate, which influences the time cattle maybe exposed to horizontal transmission, or by selective culling of seropositive animals (16).Vertical transmission of Neospora through generations of cattle appears to be the major method by which Neospora infection is maintained in herds and the role of congenital transmission of neosporosis was supported by evidence of the familial distribution of seropositive cattle through successive generations. (15, 10). The direct losses include cost of loss of the fetus, decrease in milk yield and weight gain, while the indirect costs include time for rebreeding, health costs and costs associated with culling. neosporosis is estimated to cause a loss of \$35 million per year to the Californian dairy industry alone (45), $\$ 85$ million to the australian dairy industry and \$25 million to the Australian beef industry. (1).

\section{Materials and Methods}

The study was done in Al-Muthana and AL-Nasseria provinces .800 cows( dairy $\&$ beef ) cows) ranged between 1y -
16 year during the period of March 1-32010 to June 1-6-2011.

Blood samples collection : 
The blood samples were collected from aborted and non aborted cows to detect Neospora caninum after cleaning the area by using denatured $70 \%$ medical spirit, Five $\mathrm{ml}$ of venous blood(Jugular Vein) was taken in a $10 \mathrm{ml}$ vacutinar disposable tube, the blood samples were then centrifuged at $3000 \mathrm{rpm}$ for 5 minutes and serum samples then transferred to $3 \mathrm{ml}$ sized micro test tube with screw cap and stored at $4-8^{\circ} \mathrm{C}$ for $24-48$ hrs. then the sera kept in deep freeze at $20^{\circ} \mathrm{C}$ After that the samples were transported to the laboratory in Al-Samawa hospital by cooling box. at laboratory, sera samples were examined by Elisa test according to manufacturer's instructions as follow: (w w w.diagnostics.b e).

\section{Assay Procedure:}

1. The reagents were allowed to come to room temperature $\left(18-25^{\circ} \mathrm{C}\right)$ at least 30 minutes before use.

Individual serum: Individual serum and controls have to be diluted $1 / 100$ in sample diluent solution. The positive and negative controls must always be run in duplicate.

$20 \mu \mathrm{l}$ of prediluted $1 / 20$ positive control was added to wells A1 and B1.

$20 \mu \mathrm{l}$ of prediluted $1 / 20$ negative control was added to wells A2 and B2.

$20 \mu \mathrm{l}$ of prediluted $1 / 20$ samples were added for testing to the remaining wells.

$80 \mu$ of sample diluent solution was added to each well occupied by controls and samples.then Mixed gently and the plate was covered with an adhesive plate cover (included in the kit). then Incubated for 1hour at $37 \pm 2^{\circ} \mathrm{C}$.

2- The adhesive cover was remove and the plate was washed 4 times with diluted washing solution. then all the wells were filled to the top for each wash (volume per well: $300 \mu \mathrm{l}$ ). all liquid from the wells were empted and the plate was taped hard to remove the last traces of liquid. Alternatively, the plate was washed 4 times on a automatic plate washer using a well volume of $300 \mu \mathrm{l}$.

3. $100 \mu \mathrm{l}$ of Conjugate Solution was added to each well.

4. The plate was mixed gently and covered with a new adhesive cover and incubated for 1 hour at $37 \pm 2^{\circ} \mathrm{C}$.

5.The adhesive cover was removed and the plate was washed 4 times with diluted washing solution, all the wells were filled to the top for each wash (volume per well: $300 \mu \mathrm{l})$. all liquid from the wells were empted and the plate was taped hard to remove the last traces of liquid. Alternatively, the plate was washed 4 times on a automatic plate washer using a well volume of $300 \mu$ l.

6. $100 \mu \mathrm{l}$ of substrate solution was added a to each well,then mixed gently for 2 seconds.

7. The chromogenic reaction was developed for 10 minutes at room temperature $\left(18-25^{\circ} \mathrm{C}\right)$ in the dark. the plate didn't cover.

8. $100 \mu \mathrm{l}$ of stop solution was added to each well, the stop solution was added in the same order as the substrate solution was added, the plate was mixed by gently for 2 seconds.

9. The under-surface of the plate free was wiped of dust with a soft tissue. Finally ,the plate was read using a microtiter plate reader at $450 \mathrm{~nm}$, or at dual wavelength $450-620 \mathrm{~nm}$ on a microplate reader.

\section{Calculations}

For the interpretation of results, an IRPC value is required (Relative Index x100). The following formula is applied to obtain the IRPC value (using mean $\mathrm{DO}_{405}$ values obtained for controls).

$\mathrm{IRPC}=\frac{\left(\mathrm{OD}_{405} \text { Sample Mean }-\mathrm{OD}_{405} \text { NegativeControl }\right)}{\left(\text { Mean } \mathrm{OD}_{405} \text { PositiveControl }- \text { MeanOD }_{405} \text { NegativeControl }\right)} \times 100$ 


\section{Interpretation of results:} INDIVIDUAL SERUM

\begin{tabular}{|l|l|}
\hline SAMPLE & IRPC VALUE \\
\hline Negative & $\leq 5.0$ \\
\hline Positive + & $5<$ IRPC $<25$ \\
\hline Positive ++ & $25<$ IRPC $<50$ \\
\hline Positive +++ & $50<$ IRPC $<100$ \\
\hline Positive ++++ & $>100$ \\
\hline
\end{tabular}

\section{Statistical analysis:}

Statistical analysis were conducted to determine the statistical differences among different groups using ready - made statistical design statistical package for

\section{Serological Results:}

1.indirect Enzyme linked immunsorbent assay:(iELISA):

The results of serological examination by iElisa of Neosopora caninum in cattle (Dairy \& beef ), that shown the total rate of infection was $17.5 \%(140 / 800)$, that the social science (SPSS)., Probabilities of (P< 0.05) were considered statistically significant.

Table (1): Positive number and total percentage of infected cows

\begin{tabular}{|l|l|l|l|l|}
\hline Provinces & $\begin{array}{l}\text { Total } \\
\text { samples }\end{array}$ & Positive sample & Negative sample & Seropositivity rate \% \\
\hline AL-Muthana & 300 & 48 & 252 & 16 \\
\hline Al-Nasseria & 500 & 92 & 408 & 18.4 \\
\hline Total & 800 & 140 & 660 & 17.5 \\
\hline
\end{tabular}

-Significant differences $(\mathrm{P}>0.05)$.

Table (2) Showed the distribution of seropositive cows in different age groups.the results of serpositivity rate in the age groups were highest rate was results found in AL-Muthana \& AlNasseria provinces with percentage ratio $16 \%, 18.4 \%$ respectively which was significant difference $(\mathrm{P}>0.05)$. (Table 1$)$.

Table (2): Seroprevalence of N.caninum infection in different age of cows.

\begin{tabular}{|l|l|l|l|l|}
\hline Age (Year) & Total No. & Positive No. & Seropositivity rate \% & Negative No. \\
\hline $1-4$ & 245 & 38 & 15.5102 & 207 \\
\hline $5-8$ & 347 & 74 & 21.32565 & 273 \\
\hline $9-12$ & 123 & 17 & 13.82114 & 106 \\
\hline $13-16$ & 85 & 11 & 12.94118 & 74 \\
\hline Total & 800 & 140 & 17.5 & 660 \\
\hline
\end{tabular}

-Significant differences $(\mathrm{P}<0.05)$

Table(3) Showed the results showed highest rate of Seropositivity In aborted cows $104(32.29 \%)$ than non aborted cows $36(7.53 \%)$, which was significant difference $(\mathrm{P}<0.05)$. 
Table (3): Seroprevalence of N.caninum infection in aborted and non aborted cows

\begin{tabular}{|l|l|l|l|l|}
\hline $\begin{array}{l}\text { Aborted } \\
\text { Cows }\end{array}$ & $\begin{array}{l}\text { Total } \\
\text { No. }\end{array}$ & $\begin{array}{l}\text { Positive } \\
\text { No. }\end{array}$ & $\begin{array}{l}\text { Seropositivity rate } \\
\%\end{array}$ & $\begin{array}{l}\text { Negative } \\
\text { No. }\end{array}$ \\
\hline Aborted & 322 & 104 & 32.29814 & 218 \\
\hline Non aborted & 478 & 36 & 7.531381 & 442 \\
\hline Total & 800 & 140 & 17.5 & 660 \\
\hline
\end{tabular}

-Significant differences $(\mathrm{P}<0.05)$.

As Shown table(4) the results showed the seropositive rate in dairy cows $115(19.17 \%)$ greater than from beef cows $25(12.5 \%)$. which was significant difference $(\mathrm{P}<0.05)$.

Table(4): Seroprevalence of N.caninum infection in dairy \&beef cows.

\begin{tabular}{|l|l|l|l|l|}
\hline $\begin{array}{l}\text { Dairy/Beef } \\
\text { Cows }\end{array}$ & Total No. & Positive No. & Seropositivity rate $\%$ & Negative No. \\
\hline Dairy & 600 & 115 & 19.17 & 485 \\
\hline Beef & 200 & 25 & 12.50 & 175 \\
\hline Total & 800 & 140 & 17.50 & 660 \\
\hline
\end{tabular}

-Significant difference $(\mathrm{P}<0.05)$.

\section{Discussion}

Neosporosis has been related with epizootic and sporadic abortion in dairy herds worldwide. Since the discovery of neosporosis, some studies have been conducted to assess the prevalence and to identify factors related to the disease, Prevalence's have been estimated in ranges between $16.8 \%$ and $70 \%$. $(4,10,11)$.In the present study the overall seroprevalence rate was $17.5 \%$, this result was nearly the same level as reported in China (17.2\%), Brazil (17.8\%), Spain(17.9\%) $(13,36,37)$ Also this result is lower than that reported for cattle,Spain (36.8\%), Urguay (61.3\%) Iran (46\%), Paraguay (35.7\%), Australia (24\%), Iraq (19.56\%) $(40,12,20,27,25,17)$, but higher than reported in Poland (15.6\%), Turkey (13.9\%), Canada (6.5\%), Korea (4.1\%), Italy (6\%).(26,32,33,42,34). The variation in the percentage of seroprevalence in our area and other countries may be caused by different climatic and geographical conditions or may be due to characteristics (Sensitivity and Specify ) of test used, that the prevalence based on serological tests could not be compared among countries because different tests and cut-off values were used.$(6,4,31,41)$. On the other hand this prevalence might be related to presence of many dogs which consider as definitive host in farm which the sample has been collected because of it play an important role in introduction and maintenance of the infection in herds. (44). Each results in Table (1) the infection rate in Al-Muthana and Al-Nasseria don't showed significant differences $(\mathrm{P}>0.05)$. this result is agreement with (17). The result of study showed an association between serological status and cow age and this study showed the positive seroprevalence of N.caninum increasing in age $(5-8)$ years and this is agreement with $(8,14,18)$ that they determined the risk of being seropositive may increase with age(4-8)years due to horizontal transmission of N.caninum by ingestion of oocysts shed by final host, but the result of our study is disagreement with $(12,23,42,11,9)$ that they showed no significant difference between age group, while (35)determined the seroprevalence of N.caninum increasing in age 1-3 years old. In Iran, regarded(12) the higher seroprevalence Neospora caninum in 3-4 year old cows that suggesting post natal transmission of Neospora caninum. While (14) showed that seropositivity increased with age .In Iraq, Showed (17) seropositivity prevalence rate N.caninum was $33.33 \%$ 1n $2-4$ years which greater than 5 years was lowest..The association of 
infection with abortion, in the present study showed that the prevalence of N.caninum was higher in the aborted group $104(32.29 \%)$ than non aborted group 36 $(7.53 \%)$ which was significant difference $(\mathrm{P}<0.05)$ (Table3), this result was nearly the same level as reported in New Zealand (33.6\%) (38).but disagreement with (17) in Iraq, that reported the overall seroprevalence of Neospora caninum in three provinces (Dawania ,Nasseria, Basrah) was $19.56 \%$.Also this result is different in parts of the world that reported for aborted cattle Japan 145(20\%), Poland 45(15.6\%), Argentina 189(64.5\%), Hungary 97(10\%), Sweden 70(63\%)United Kingdom 95(60\%). (24,26,21,22,28,29). This variation in the percentage of seroprevalence in the countries may be due to different in numbers of examined animals(aborted cattle) or to different tests were used or to the point source exposure to N.caninum oocysts which excreted by final host (dogs) (19). While (30) found the abortion storm in cattle due to that $N$.caninum was introduced to the region by imported cattle and therefore risk of vertical transmission to fetuses and abortion was important. A possible explanation for the fact that many non aborting cows were seropositive relates to the pathogenesis of disease and the host immune system, that these cows may have been infected with the parasite but the number of N.caninum tachyzoite in the host tissue may not have enough to cause clinical symptoms. abortion.(7).Observed (5) a markedly increased abortion risk in congenitally infected heifers during their first gestation but not in later gestation compared to abortion risk in seronegative controls.Seroepidemiological studies have assessed the increased risk for abortion in seropositive cows $(11,41)$.In Table (4) the present study showed that the prevalence of $N$. caninum was higher in the dairy cows $115(19.17 \%)$ than beef cows 25 $(12.50 \%)$ this result was nearly the same level as reported in Brazil (18.60\%), in dairy cows and (12.9\%) in beef cows. (19).Beef and dairy herds are managed in different production system ,beef cattle are usually raised in extensive grazing system whereas dairies are intensively exploited (39).Differences in the management between dairy and beef herds could explain the high prevalence of neosporosis found in dairy compared with that in beef cattle, also postnatal transmission could be more frequent in dairy cattle because they are more intensively exploited than beef cattle.(31). While (43) found that the differences in infection between dairy and beef cattle generally that beef cattle raised under less stressful conditions such as winter stocking density, more regular stock movement than dairy cattle, while the dairy cattle that more supplemental feeding practices ,frequent regular stock movement, high stocking density of cattle may increase the risk of horizontal transmission through a definitive host.

\section{References}

1. Dubey, J.P.( 1992). A review of Neospora caninum and Neospora-like infections in animals. J. Protozool. Res. 2: 4052.

2. Dubey, J.P. and Lindsay, D.S.( 1993). Neosporosis. Parasitol. Today. 9: 452-458.

3. Hemphill,A. Fuchs,N. Sonda, S. and Hehl, A.(1999).The antigenic composition of Neospora caninum. Int.J.Parasitol.29:11751188.

4. Paré, J. Thurmond, M.C. and Hietala, S.K. (1997). Neospora caninum antibodies in cows during pregnancy as a predictor of congenital infection and abortion. J. Parasitol. 83: 82-87.

5. Thurmond, M.C. and Hietala, S.K. (1996). Culling associated with Neospora caninum infection in dairy cows. Am. J. Vet. Res. 57: 1559-1562.

6. Trees, A.J. Guy, F. Low, J.C. Roberts, L. Buxton, D. and Dubey, J.P. (1994).Serological evidence implicating Neospora species as a cause of abortion in British cattle. Vet. Rec. 134: 405-407. 
7. Conrad, P.A. Barr, P.A. Sverlow, K.W. Anderson, M. Daft, B. Kinde, H. Dubey, J.P. Munson, L.and Ardans, A. (1993). In vitro isolation and characterization of a Neospora sp. fromaborted bovine fetuses. Parasitol. 106: 239-249.

8. Dubey, J.P. Schares, G. and OrtegaMora, L.M. (2007) Epidemiology and control of neosporosis and Neospora caninum. Clin. Microbiol. Rev. 20:323-367.

9. Davison, H. C. Otter, A. and Trees, A. J. ( 1999). Estimation of vertical and horizontal transmission parameters of Neospora caninum infections in dairy cattle.Int. J.Parasitol. 29, 1683-1689.

10. Thurmond, M.C. Hietala, S.K.and Blanchard, P.C.( 1997). Herd-based diagnosis of Neospora caninuminduce endemic and epidemic abortion in cows and evidence for congenital and postnatal transmission. J. Vet. Diagn. Invest 9: 44-49.

11. Waldner, C.L. Janzen, E.D.and Ribble, C.S. (1998). Determination of the association between Neospora caninum infection and reproductive performance in beef herds. J. Am. Vet. Med.Assoc. 213: 685-690.

12. Razmi, G. R. Mohammadi, G. R. Garrosi, T. Farzaneh, N. Fallah, A. $\mathrm{H}$ and Maleki, M. (2006). Seroepidemiology of Neospora caninum infection in dairy cattle herds in Mashhad area, Iran. Vet. Parasitol. 135:187-189.

13. Yu, J. Liu, Q. Xia, Z. Liu,J. Ding, J. and Zhang,W .(2007). Seroepidemiology of Neospora caninum and Toxoplasma gondii in cattle and water buffaloes (Bubalus bubalis) in the People's Republic of China. Vet. Parasitol. 143:79- 85 .

14. Jensen, A. M. Bjorkman, C. Kjeldsen, A. M. Wedderkopp, A. Willadsen, C. Uggla, A. and Lind, $\mathrm{P}$.(
1999). Associations of Neospora caninum seropositivity with gestation number and pregnancy outcome in Danish dairy herds. Prev. Vet. Med. 40:151-163.

15. Pare', J. Thurmond, M.C and Hietala, S.K.( 1994). Congenital Neospora infection in dairy cattle. Vet .Rec 134:531-532.

16. Bartels, C.J.M. Arnaiz-Seco, J.I. RuizSanta-Quitera, A. Bjorkman, C.Fro ssling, J. von Blumroder, D. Conraths, F.J. Schares, G. van Maanen, C. Wouda, W. and Ortega-Mora, L.M. (2006). Supranational comparison o Neospora caninum seroprevalences in cattle in Germany, the Netherlands, Spain and Sweden. Vet. Parasitol. 137: 17-27.

17. Nema-Alhindawe, A.J. (2010). Seroprevalence of Neospora caninum In cattle in Some provinces in IraQ. $4^{\text {th }}$ Sci.Congr. of Egypt .Soc. for Anim.Manag.25280ct: $189-200$.

18. Woodbine,K.A. Graham, F. M. Moore, S.J. Ramirez-Villaescusa, A. Mason ,S and Laura ,E. G.(2008). A four year longitudinal seroepidemiology study of Neospora caninum in adult cattle from 114 cattle herds in south west England: Associations with age, herd and dam- offspring pairs Vet. Res. 4:1-12.

19. Barling, K.S. Sherman, M. Peterson, M.J. Thompson, J.A. McNeill, J.W.Craig, T.M.and Adams, L.G. (2000). Spatial associations among density of cattle, abundance of wild canids and seroprevalence to Neospora caninum a population of beef calves. J. Am. Vet. Med. Assoc.217: 1361-1365.

20. Atkinson, R. A. Cook, L. A. Reddacliff, J. Rothwell, K. W. Broady, P. A. W. Harper, and J. T. Ellis. (2000). Seroprevalence of Neospora caninum infection following an abortion outbreak in a 
dairy cattle herd. Aust. Vet.J. 78:262-266.

21. Venturini, M. C. Venturini, L. Bacigalupe, D. Machuca, M. Echaide, I. Basso, W. Unzaga, J. M. Di Lorenzo, C. Guglielmone, A. Jenkins, M. C. and Dubey, J. P.(1999). Neospora caninum infections in bovine fetuses and dairy cows with abortions in Argentina. Int. J. Parasitol. 29:1705-1708.

22. Hornok, S. Naslund, K. Hajto's, I. Tanyi, J. Tekes, L. Varga, I. Uggla, A. and Bjorkman, C. (1998). Detection of antibodies to Neospora caninum in bovine post abortion blood samples from Hungary. Acta Vet. Hung. 46: 431436.

23. Sadrebazzaz, A. Haddadzadeh, H. Esmailnia, K. Habibi, G. Vojgani, M. and Hashemifesharaki, R.( 2004). Serological prevalence of Neospora caninum in healthy and aborted dairy cattle in Mashhad, Iran. Vet. Parasitol.124:201-204.

24. Koiwai, M. Hamaoka, T. Haritani, M. Shimizu, S. Tsutsui, T. Eto, M. and Yamane, I. (2005). Seroprevalence of Neospora caninum in dairy and beef cattle with reproductive disorders in Japan. Vet. Parasitol. 130:15-18.

25. Osawa, T. Wastling, J. Acosta, L. Ortellado, C. Ibarra, J. and Innes, E. A.(2002). Seroprevalence of Neospora caninum infection in dairy and beef cattle in Paraguay. Vet. Parasitol. 110:17-23.

26. Cabaj, W. Choromanski, L. Rodgers, S. Moskwa, B. E. and Malczewski, A.(2000). Neospora caninum infections in aborting dairy cows in Poland. Acta.Parasitol. 45:113114 ..

27. Quintanilla-Gozalo, A. Pereira-Bueno, J. Tabare's, E. Innes, E. A.Gonza'lez-Paniello, R. and Ortega-Mora, L. M. (1999). Seroprevalence of Neospora caninum infection in dairy and beef cattle in Spain. Int. J. Parasitol. 29:1201-1208.

28. Stenlund, S. Kindahl, H. Magnusson, U. Uggla, A. and Bjorkman, C. (1999). Serum antibody profile and reproductive performance during two consecutive pregnancies of cows naturally infected with Neospora caninum. Vet. Parasitol. 85:227-234.

29. Dannatt, L. (1997). Neospora caninum antibody levels in an endemically infected dairy herd. Cattle Practice 5:335-337.

30. Akca, A. Gokce, H. I. Guy, C. S. McGarry, J. W. and Williams D. J.(2005). Prevalence of antibodies to Neospora caninum in local and imported cattle breeds in the Kars province of Turkey. Res. Vet. Sci.78:123-126.

31. Moore, D. P. (2005). Neosporosis in South America. Vet. Parasitol. 127: 87-97.

32. Waldner, C. L. Wildman, B. K. Hill, B. W. Fenton, R. K. Pittman, T. J.Schunicht, O. C. Jim, G. K. Guichon, P. T. and Booker, C. W. (2004).Determination of the seroprevalence of Neospora caninum in feedlot steers in Alberta. Can. Vet. J. 45:218-224.

33. Otranto, D. Llazari, A. Testini, G. Traversa, D. Di Regalbono, A. F.Badan, M.and Capelli, G. (2003). Seroprevalence and associated risk factors of neosporosis in beef and dairy cattle in Italy. Vet. Parasitol.118:7-18.

34. Kim, J. H. Lee, J. K. Hwang, E. K. and Kim, D. Y. (2002). Prevalence of antibodies to Neospora caninum in Korean native beef cattle. J. Vet. Med. Sci. 64:941-943.

35. Sanderson, M. W. Gay, J. M. and Baszler, T. V. (2000). Neospora caninum seroprevalence and associated risk factors in beef cattle in the northwestern United States. Vet. Parasitol. 90:15-24.

36. Corbellini, L. G. Smith, D. R. Pescador, C. A. Schmitz, M. 
Correa, A.Steffen, D. J. and Driemeier, D. (2006). Herd-level risk factors for Neospora caninum seroprevalence in dairy farms in southern Brazil. Prev. Vet. Med.74:130-141.

37. Quintanilla-Gozalo, A. Pereira-Bueno, J. Seijas-Carballedo, A. Costas, E.and Ortega-Mora, L. M. (2000). Observational studies in Neospora caninum infected dairy cattle: relationship infection-abortion and gestational antibody fluctuations. Int. J. Parasitol. 30:900-906.

38. Reichel, M. P. and Pfeiffer, D. U. (2002). An analysis of the performance characterisics of serological tests for the diagnosis of Neospora caninum infection in cattle. Vet. Parasitol. 107:197-207.

39. Carrillo,J.and Schiersmann, G.(1992). Beef cattle production in the temperate Zone of South America. (Argentina, Uruguay) .Vet. Parasitol. 107:303-316.

40. Kashiwazaki, Y. Pholpark, S. Charoenchai, A. Polsar, C. Teeverapanya, S.and Pholpark, M. (2001). Postnatal neosporosis in dairy cattle in northeast Thailand. Vet. Parasitol. 94:217-220.
P.A.( 1998).First report of bovine neosporosis in dairy cattle in Costa Rica. Vet. Rec. 142: 520-521.

42. Vural, G. Aksoy, E. Bozkir, M. Kucukayan, U. and Erturk, A. (2006).Seroprevalence of Neospora caninum in dairy cattle herds in Central Anatolia, Turkey. Vet. Arh. 76:343-349.

43. Kim, J. H. Kang, M. S. Lee, B. C. Hwang, W. S. Lee, C. W So, B. J.Dubey, J. P. and D. Kim, Y. (2003). Seroprevalence of antibodies to Neospora caninum in dogs and raccoon dogs in Korea. Korean J. Parasitol. 41:243- 245.

44. Dubey, J.P.(1999). Neosporosis in cattle biology and economic impact. J.Am. Vet. Med. Assoc. 214, 1160-1163.

45. Anderson, M.L.; Palmer, C.W.; Thurmond, M.C.; Picanso, J.P. Blanchard, P.C.; Breitmeyer, R.E.; Layton, W.; McAllister, M.; Daft, B.; Kinde, H.; Read, D.; Dubey, J.P.; Conrad, P.A. and Barr, B.C. (1995). Evaluation of abortions in cattle attributable to neosporosis in select dairy herds in California. J. Am. Vet.Med. Assoc., 9: 12061210.

41. Perez, E. Gonzalez, O. Dolz, G. Morales, J,A. Barr, B. and Conrad,

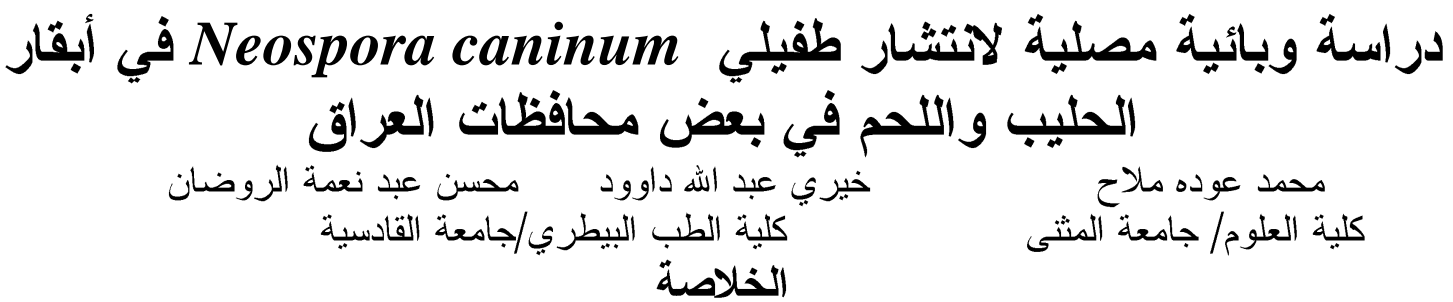

تم إجر اء در اسة مصلية وبائية في انتشار البوغية الكلبية الجديدة N.caninum في محافظتي المثنى و الناصرية, علـى الإيق

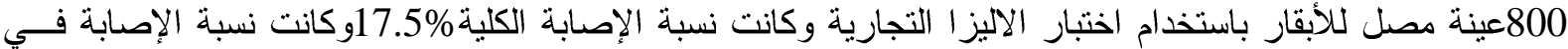

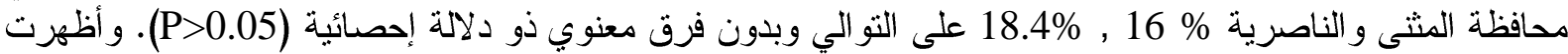

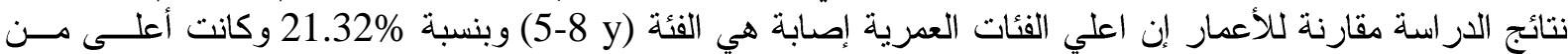

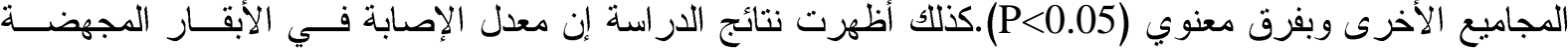

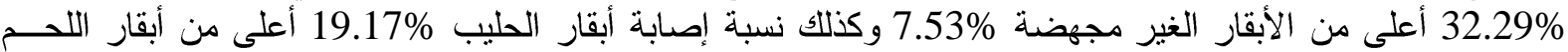
12.5\% وبفرق معنوي ذو دلالة إحصائية (P<0.05), نتائج الدراسة تثير إلى انتشار الطفيلي في محافظات العراق. 